\title{
Charter Cities And The Aerotropolis In Colombia
}

Roger Morefield, University of Saint Thomas, USA

David Strong, Our Lady of the Lake University - Houston, USA

\begin{abstract}
Based on its income per capita, Colombia meets the World Bank criteria for classification as an upper middle income country, but it still has many of the earmarks of a developing country, including its high poverty rate (45\%), high infant mortality (16 deaths per 1000 live births), and lower life expectancy (74 years) than most developed countries. The capital city, Bogota, contains one-fifth of Colombia's population, which is typical of the "urban giantism" of developing countries. Colombia's income inequality is acute, with the lowest decile of households receiving $0.8 \%$ of household incomes, while the highest decile receives $45 \%$. This results in a Gini coefficient of 58 the ninth highest in the world. The paradox is that while Colombia's per-capita GDP and GNI indicate that it is an upper-middle income country, its poverty, income inequality, infant mortality rate, and other socioeconomic indicators look very much like those of a low-income country. This raises an interesting question: "How can Colombia continue its development, presumably toward becoming a high-income country, while it is addressing its disproportionate poverty levels and income inequality?"
\end{abstract}

This paper investigates the prospects and challenges of implementing two relatively new ideas in economic development. The first is the use of Paul Romer's idea of charter cities to enhance economic development in Colombia. Charter cities could be used to create more dynamic enterprise zones than now exist in Colombia. Romer advocates that countries set aside currently uninhabited city-size special reform zones to be charter cities. These cities would have a charter or constitution which specifies the governing rules - good rules (or institutions) - which would be supportive of entrepreneurial activity and a robust business climate. Charter cities could presumably be like a "clean slate" without all the developing-country plethora of rules and regulations that hinder development in established cities such as Cairo and Mumbai. Romer cites the example of Hong Kong as an extraordinarily successful early type of charter city which was governed by different rules for 99 years before it was ceded back to the People's Republic of China by Great Britain in 1997. The second type of development tool for Colombia explored in this paper is John Kasarda's "aerotropolis." An aerotropolis is a city built around an airport. Traditional cities sprang up around existing trade routes along navigable waterways or where road and railroads met and crossed. The twenty-first century equivalent of that, according to Kasarda, is where "highways in the sky" interact with productive facilities on the ground at or near airports to be part of an ever-growing global supply chain. In this paper, some possible locations for charter cities and aerotropolises in Colombia are explored and their economic impact is assessed. The paper concludes that both can assist Colombia in reducing poverty and income inequality, but with certain qualifications. It also suggests that a hybrid of the two, an aerotropolis that is also a charter city, can significantly contribute to Colombia's economic development.

Keywords: Colombia; Economic Development; Charter Cities; Aerotropolis; Free Trade Zones

\section{INTRODUCTION}

olombia, South America, has made substantial progress since 1990. Real GDP grew 54\% from 1990 to 2005 (DANE, 2011). Gross National Income (GNI) Per Capita in Purchasing Power Parity (PPP) dollars rose 243\% from 1980 to 2009 (World Bank, 2011). Substantial progress against the production and distribution of illegal drugs was made, with illegal drugs falling from $6.3 \%$ of Colombian GDP in 1987 to less than 1\% in 2010 (Bristow, 2010). With its 2009 Per Capita GNI at \$4,990, Colombia is now classified as an "Upper Middle Income" country in the World Bank's income groups. 
There are a number of socioeconomic indicators which help paint a picture of the welfare of people in a country. It is informative to look at these indicators for Colombia to get the parts of the picture that can't be revealed by per-capita GDP figures alone. Relative poverty levels in rich countries tend to run $20 \%$ or less, but Colombia's rate is more than double that at $45.5 \%$. Although this rule doesn't always hold, income inequality, as measured by the Gini Index, tends to be higher in low-income countries than in high-income countries. Income inequality in Colombia, as measured by its Gini Index of 58.5, is greater than all but seven countries listed in the CIA World Factbook (2011). The highest quintile of income earners in Colombia receives $61 \%$ of incomes, while the lowest receives 3\%. The Gini index rose from 53.8 in 1996 to 58.5 in 2009, seemingly indicating that Colombia's rise from a lower-middle income country to an upper-middle-income country made the poorest of the poor in Colombia relatively worse off.

Other socioeconomic indicators for Colombia also indicate its recent past as a developing country. The median age is 28 years, compared to 36.8 for the United States, 40.7 for Canada, and 43.7 for Germany. Colombia's population growth rate is $1.2 \%$, compared to $0.96 \%$ for the US, $0.8 \%$ for Canada, and $-0.21 \%$ for Germany. Its birth rate (births/1,000 population) is 17.5 , compared to the US at 13.8, Canada at 10.3, and Germany at 8.3 (CIA 2011).

Colombia's record of growth and development is commendable but masks certain somber realities that it must face. Although significant reductions in poverty have been achieved, it is still uncomfortably high. Although Colombia is said to be the third happiest country in the world (Mabe, 2008), its high income inequality and high poverty rates need to be addressed. This paper raises the question, "Can the relatively new twin ideas, charter cities, and the aerotropolis be utilized to reduce poverty and income inequality in Colombia?"

\section{THE CHARTER CITIES MOVEMENT}

The idea of charter cities has been around in one form or another since Henry the Lion founded Lübeck in what is now the German state of Schleswig-Holstein on the Baltic Sea. More recently, the strongest proponent of charter cities has been Paul Romer, a former Stanford University development economist. From 2001 to 2007, Romer virtually revolutionized instruction in economics with his online homework system - Aplia. He sold Aplia in 2007 and in 2008 organized his charter cities campaign.

A charter city is a type of special economic zone which is supposed to function better than a traditional city because it is governed by rules that allow more flexibility, creativity, and entrepreneurial activity. Although the concept is quite flexible, charter cities would share the following elements:

1. A vacant piece of land, large enough for an entire city

2. A charter that specifies in advance the broad rules that will apply there

3. A commitment to choice, backed by both voluntary entry and free exit for all its residents

4. A commitment to the equal application of all rules to all residents (Charter Cities, 2011)

The tract of land could be about 1,000 $\mathrm{KM}^{2}$ (386 square miles). For the charter rules, Romer draws on his academic work about "ideas" and "good rules" being the sources of economic growth (Jones and Romer 2009; Romer 1986). Residents would be free to enter and exit the city, so there would be no requirement for anyone who didn't agree with the charter to migrate there. A controversial part of the charter city's structure is Romer's idea that there could be as many as three countries involved - a host country that provides the land, a source country that supplies the people, and a guarantor country that provides for enforcement of the charter. Romer cites Hong Kong as a prototype charter city. Hong Kong was leased by China to the United Kingdom for 99 years, from 1898 to 1997. In charter cities parlance, China supplied the land and the people, and the UK was the guarantor, but there could be other combinations, such as one country being host and guarantor while another supplies the people. Another possible combination is for one country to do all three.

\section{CHARTER CITIES AND ECONOMIC DEVELOPMENT}

The charter cities movement has not had what could be termed a major victory as of this writing, but it is not something to be quickly dismissed. First, such a movement will likely take years, perhaps decades, to produce 
visible results, and at this writing, the movement is only three years old. Second, it could actually take more time to get governments to agree to found charter cities than it would to actually build one. In 2011, the government of Honduras authorized the creation of "special development regions" and on December 6, 2011, Honduran President Porfirio Lobo appointed several members to a so-called "transparency commission" which is supposed to provide oversight against corruption in these regions, so it is possible that Paul Romer will see the first fruits of his efforts near the little town of Trujillo (population 5,774) on the northern coast of Honduras ("Hong Kong" 2011).

\section{THE AEROTROPOLIS}

For several decades, Dr. John Kasarda of the University of North Carolina has promoted an idea he now calls the "aerotropolis." After engaging in planning and promoting "global transparks" and "global transpark cities" (Kasarda, Rondinelli \& Ward, 1996), Kasarda began to use the term aerotropolis to refer to "... a new urban form placing airports in the center with cities growing around them, connecting workers, suppliers, executives, and goods to the global marketplace" (Kasarda, 2011a). Goods that travel by air comprise about one-third of the value of all goods made worldwide but only one percent of the weight. Trade and commerce in these goods has become increasingly concentrated near airports, also attracting all kinds of related services. According to Dr. Kasarda, rather than trying to avoid the airport by building it as far from the city as possible, cities should be centered around the airport (Kasarda and Lindsey, 2011). In his view, the city of the future is a planned development with an airport at its center. His vision of this idea is shown in Figure 1. The facilities shown may be located in a radius of up to twenty miles from the airport runways.

In Figure 1, airport planning, urban planning, and business site planning are combined to locate the city around the airport runways. Features, such as the logistics park, free-trade zone, distribution centers, and just-in-time manufacturing, are located near the runways for greater speed out of and back into the air. Other amenities, such as residential areas, are located further from the runways to be as far away as possible from the noise and pollution of takeoffs and landings but to still be only a short distance from the airport terminal.

Kasarda has described the aerotropolis as the "fifth wave" of urban development. The first wave was around seaports, the second along rivers and canals. The third wave was ushered in by railroads and the fourth by networks of highways. The fifth wave is now being driven by the phenomenon of "airports as the primary drivers of urban growth, international connectivity, and economic success. Speed now matters most" (Derewicz, 2011, p. 27). The first and second waves may be thought of as phenomena of the eighteenth century, the third wave the nineteenth, the fourth wave the twentieth, and the fifth wave the twenty-first. Since the trade routes of the future are highways in the sky, the aerotropolis is the next logical step. Even traditional cities may reform themselves in this pattern. There is a kōan about the city of Amsterdam and its Schipol airport that says (Kasarda \& Lindsay 2011):

The airport leaves the city; the city follows the airport; the airport becomes the city.

An aerotropolis can be formed around an existing airport, although local residents and business owners who are negatively affected by it are likely to create numerous obstacles using lawsuits and lengthy environmental impact studies and hearings. Logistically, it is much easier to use a "greenfield" approach; that is, carefully planning the project, acquiring a parcel of unused land for it and then building it according to plan. Kasarda has also identified "airport cities" which are areas that have the inner ring of an aerotropolis but are missing substantial parts of the integrated planned model (Kasarda, 2011). Whether it is about an existing airport becoming an aerotropolis or airport city, or a new aerotropolis being built on formerly vacant land, the idea is to attract goods and services production to the region to create jobs, raise incomes, and stimulate local economic development. 


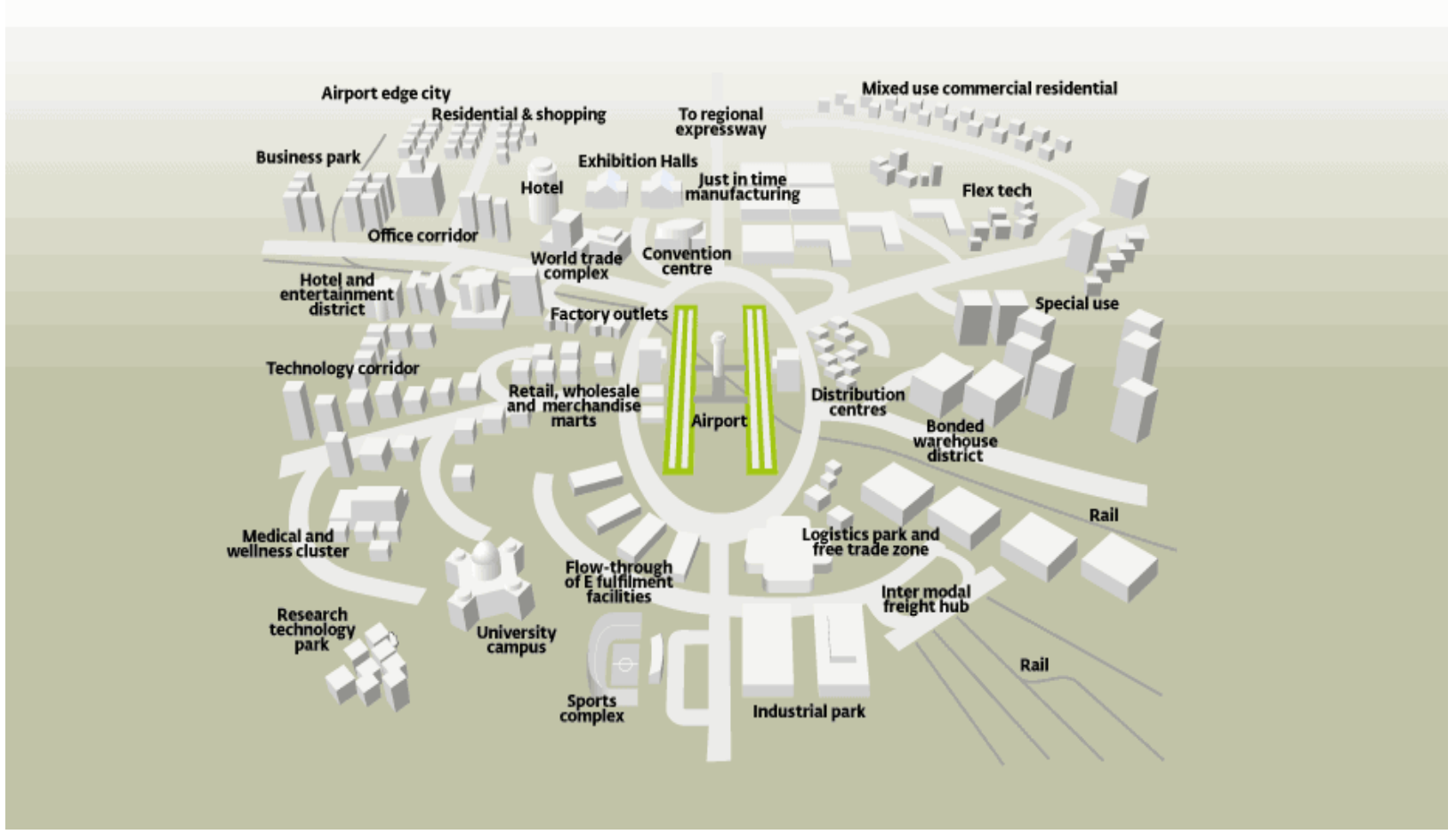

Figure 1: John Kasarda's Vision of the Aerotropolis (from Kasarda \& Lindsey, 2011)

\section{THE AEROTROPOLIS AND ECONOMIC DEVELOPMENT}

In the United States, there are 10 operational aerotropolises, 20 developing aerotropolises, six operational airport cities, and 10 developing airport cities. Globally, there are 24 operational aerotropolises, 16 operational airport cities, 51 developing aerotropolises, and 21 developing airport cities (Kasarda, 2011b). The aerotropolis is transforming areas where it is in use, at least according to claims made by local authorities. Memphis International Airport, now calling itself "America's Aerotropolis ${ }^{\text {TM }}$," claims to have revitalized a traditional second wave city by bringing $\$ 28$ billion and 220,000 jobs to the economy of the region. A similar claim is made for the Dallas-Fort Worth International Airport, an operational aerotropolis that generates $\$ 16$ billion annually and is the basis for 300,000 jobs in the North Texas economy. A planned aerotropolis for Southeast Michigan would connect two airports, Detroit Metropolitan and Willow Run - which are located seven miles apart. It is hoped that the DetroitWillow Run aerotropolis will bring much-needed economic revitalization to an area devastated by the decline of the US auto industry ("Rise of...", 2010).

South of the US border, the situation is quite different. In Latin America, there is only one operational aerotropolis and one developing aerotropolis. The Tancredo Neves International Airport in Belo Horizonte, in the State of Minas Gerais, Brazil, is an operational aerotropolis and the Panatropolis at Tocumen International Airport in Panama City, Panama, is a developing one. The progress of the Belo Horizonte aerotropolis has been significantly impeded by its 24 -mile distance from downtown and the very bad access road linking the two. To address these issues, the state and national governments have recently improved the access road and authorized a free trade zone at the airport (Kasarda 2007). The Panatropolis in Panama City is an ambitious effort to grow the airport into an aerotropolis that will rival the super-sized ones in Dubai and Incheon. Since the project was only officially announced in late 2010, it has not had sufficient time to materialize. Based on this, the aerotropolis has no established track record in Latin America. However, proponents of the aerotropolis continue to promote it as a way to compete effectively for business that is currently going to China and other parts of the Asia/Pacific region. 


\section{CHARTER CITIES AND THE AEROTROPOLIS COMBINED}

As noted earlier, there is a significant advantage to building a "greenfield"-style aerotropolis. Such a project could also be founded as a charter city, combining the strengths of the two. A charter aerotropolis could be built on land supplied by the host country, such as Colombia, staffed by Colombians, and given guarantor oversight by a third country, such as Canada or New Zealand. The existence of charter-city-style flexible rules would make the charter aerotropolis very competitive.

\section{REGIONAL INEQUALITY IN COLOMBIA}

Geographical regions in Colombia are called departments and Colombia has 25 of them. An additional feature of Colombia's income inequality is the large variations in per-capita incomes among departments. LópezRodriguez and Acevedo (2009) found that Per Capita Gross Departmental Revenue [as a proxy for per-capita income] was more than eight times higher in the richest department, Bogotá, than in the poorest, Chocó. They also found that, in general, the nine poorest departments [Caquetá, Cauca, Cesar, Chocó, Magdelena, Nariño, Norte de Santander, and Sucre] are located on the nation's coastal periphery and are further from Bogotá than the richest. Their econometric estimates indicate that if a department's market access increased by $1 \%$, nominal wages could increase between $0.9 \%$ and $1.6 \%$, depending on other factors. These findings make the case for a regional development strategy that would focus on these coastal and outlying areas. Table 1 shows Per Capita GDR statistics for all 25 departments between 1975 and 2000.

\section{CHARTER CITIES, THE AEROTROPOLIS, AND COLOMBIAN ECONOMIC DEVELOPMENT}

As patterns of trade and commerce reform the traditional city and affect the shape of newly planned ones, it is important to assess how these new cities may affect economic development in emerging economics, such as Colombia. It is also important to discuss the potential effects on income inequality and poverty that the accession of this new urban model may have on these economies.

In early 2011, China and Colombia announced that they were working on a conceptual "dry canal" to connect Colombia's Caribbean coast with its Pacific coast by railway. This proposal is the most recent of a series of proposals that have been made to provide competition for the Panama Canal. The "dry canal" would be located in Chocó department near the border with Panama. Its rail line would be about 137 miles long and a new port city would be built near Cartagena. This proposal immediately raised questions about its viability. It is not likely to be cost competitive as it would take 80 trainloads to equal the capacity of one ship going through the Panama Canal. There is also speculation that what China really wants is Colombian coal and may want to use the "dry canal" to ship much-needed coal to a port on Colombia's Caribbean coast. There is also speculation that favorable comments about the project by the Colombian President, Juan Manuel Santos, were just political posturing to get the United States to move more quickly toward ratifying the long-delayed Colombia-United States Trade Agreement (Sequera, 2011).

Economic development in Colombia must be supported by additional infrastructure, especially for its transportation needs. Since the nine poorest departments lack market access, transportation is a very important element for rising incomes in these areas. Although the Colombian government projects infrastructure spending of $\$ 50$ billion over the next ten years (U.S. Congress, 2011), it is likely that this is not nearly enough. This is especially true given that the projected $\$ 5$ billion per year must be spread over spending for telecommunications, energy and electricity generation, tourism, and transportation. Therefore, it is important that additional sources be available. If aerotropolis and charter aerotropolis projects are started in Colombia, it is important that private interests are attracted. Private-sector participation in such projects would be a much-needed enhancement to the meager levels of spending planned by the government in Bogotá.

If new charter cities, aerotropolises, or charter aerotropolises are built in Colombia, every effort should be made to place them in one of the nine poorest departments listed earlier in this paper. Colombia has 12 international airports and an additional 39 "controlled" airports; that is, airports with a control tower. The two existing airports in these departments that could most easily be expanded into aerotropolises are Simón Bolivar International in Santa 
Marta and Camilo Daza International in Cúcuta. In addition, 12 of Colombia's controlled airports are in the nine poorest departments. However, these airports tend to have one fairly short runway of unreinforced asphalt about 4,000 feet long, which is inadequate for today's Boeing 747F and Airbus A330 large freighters. Even the runways in Santa Marta and Cúcuta would likely need reinforcement and lengthening to handle landings of these large heavy planes; so converting any of these facilities into an aerotropolis would require significant investment in reinforced, lengthened and widened runways, in addition to the needed terminal facilities and other enhancements.

Table 1: Per Capita Gross Departmental Revenue (from Lopez-Rodriguez and Acevedo, 2009)

\begin{tabular}{|c|c|c|c|c|c|}
\hline Department & $1975-1980$ & 1981-1985 & 1986-1990 & 1991-1995 & 1996-2000 \\
\hline Antioquia & 39237 & 126148 & 454078 & 1545592 & 3626780 \\
\hline Atlántico & 39158 & 134177 & 436388 & 1355559 & 2913580 \\
\hline Bogotá & 77983 & 255225 & 896778 & 3177581 & 7847582 \\
\hline Bolívar & 27387 & 87113 & 296440 & 967827 & 2267587 \\
\hline Boyacá & 26125 & 82592 & 270908 & 953614 & 2212812 \\
\hline Caldas & 28062 & 87437 & 292598 & 1000896 & 2346573 \\
\hline Caquetá & 18998 & 58280 & 195515 & 597862 & 1439075 \\
\hline Cauca & 18383 & 61883 & 201906 & 755283 & 1635055 \\
\hline Cesar & 21744 & 64201 & 210785 & 781666 & 1848724 \\
\hline Córdoba & 19055 & 52917 & 170530 & 591007 & 1494216 \\
\hline Cundinamarca & 26972 & 90396 & 312591 & 1140496 & 2697816 \\
\hline Chocó & 8516 & 25151 & 105204 & 387554 & 965927 \\
\hline Huila & 26121 & 83150 & 247202 & 890494 & 2170807 \\
\hline La Guajira & 12808 & 56582 & 242267 & 825042 & 1892829 \\
\hline Magdalena & 17861 & 58532 & 191984 & 684531 & 1618720 \\
\hline Meta & 28725 & 89932 & 310787 & 987355 & 2452051 \\
\hline Nariño & 12969 & 46904 & 150252 & 440807 & 1098774 \\
\hline Norte de Santander & 21028 & 67520 & 226716 & 789482 & 1662103 \\
\hline Quindío & 31283 & 103007 & 337425 & 1048494 & 2148652 \\
\hline Risaralda & 30297 & 98301 & 318364 & 1079318 & 2400146 \\
\hline Santander & 32086 & 104426 & 338456 & 1114954 & 2665781 \\
\hline Sucre & 16117 & 45844 & 159258 & 548684 & 1282288 \\
\hline Tolima & 24652 & 74382 & 248581 & 874924 & 2239826 \\
\hline Valle & 42526 & 138925 & 463175 & 1614317 & 3392979 \\
\hline Nuevos & 26048 & 76506 & 335348 & 1058339 & 2662488 \\
\hline pc GDR mean & 32806 & 107461 & 363651 & 1331275 & 3276619 \\
\hline Bogotá/mean pc GDR & 2.38 & 2.38 & 2.47 & 2.39 & 2.40 \\
\hline Lowest pc GDR & 8516 & 25151 & 105204 & 387554 & 965927 \\
\hline Bogotá/Lowest pc GDR & 9.16 & 10.15 & 8.52 & 8.20 & 8.12 \\
\hline
\end{tabular}

Colombia badly needs more and better roads (Olivera, 2009). Residents complain bitterly of the difficulty and risk to personal safety of driving between Bogotá and the other major cities (Mario Rocha, personal communication, December 9, 2011). Road density is defined as kilometers of road per square kilometer of land. Colombia's road density of 14.8, compares with the US at 68, Canada at 14, and Germany at 181. Even though Canada has millions of square kilometers of uninhabited frozen tundra, its road density is comparable to that of Colombia. Given the low number and quality of Colombian roads, the fact is that for any aerotropolis or charter aerotropolis to be successful it must be connected to the rest of the country by safe, wide, smooth, paved, and relatively uncongested roads. 
Railway density is another helpful concept. Railway density is meters of railway line per 1,000 inhabitants. The United States has 36 times more railway line than Colombia; Canada has 70 times and Germany 26 times. It is essential that aerotropolises, charter cities, and charter aerotropolises in Colombia be supported by networks of highquality, well-maintained railroads for moving raw materials, goods, and people to and from markets and workplaces.

\section{INTERPRETATIONS AND CONCLUSIONS}

How many jobs might be created in Colombia by an aerotropolis, charter city, or charter aerotropolis? Any reliable estimates would need to be based on numerous assumptions about sufficiency of infrastructure and other factors. A rough estimate could be made, however, based on the population of the new city or aerotropolis. Suppose that a city of 250,000 were to spring up near a new railway line connecting Colombia's Atlantic and Pacific coasts. Since Colombia has an employment to population ratio of 0.62 (Trading Economics, 2011), as many as 150,000 jobs could be created. This ignores secondary and tertiary employment effects, as well as the possibility that some of these jobs are existing jobs moving from other parts of the country. An additional 150,000 jobs would bring Colombia's unemployment rate down from its current $11.8 \%$ to $11.1 \%$; but if secondary and tertiary effects are considered, the impact could be doubled. That is, 150,000 new primary jobs in Colombia could create 150,000 more, bringing the $11.8 \%$ unemployment rate down to $10.4 \%$. However, this is a short-run analysis of the potential impact of a long-run project, so the long-run impact could be much larger.

Bringing charter cities, aerotropolises, and charter aerotropolises to life in Colombia will require strong public support and unflinching dedication by the national and local governments to see these projects to their successful completion. Colombia has taken bold steps in recent decades to enact pro-business reforms and improve internal security. It remains to be seen if Colombia's leadership and people will want to use the aerotropolis and the charter city to help reduce its unacceptably high levels of poverty and income inequality.

\section{AUTHOR INFORMATION}

Dr. Roger Morefield is an Associate Professor of Economics at the University of Saint Thomas in Houston, Texas. He joined the University of Saint Thomas in 1980 and teaches undergraduate and MBA classes. Dr. Morefield received his PhD. in Economics from Duke University in 1977, an M.A. in Economics from Duke in 1975, and a B.S. in Business and Economics from the University of Alabama at Birmingham in 1972. He has authored and coauthored several refereed journal and proceedings articles. His primary research interests are environmental economics, international trade, urban and regional economics, economic education, and industrial organization. E-mail: mofield@stthom.edu (Corresponding author)

Dr. David Strong is a Master Faculty Professor of Business at LeTourneau University and Adjunct Management Professor at Our Lady of the Lake University in Houston, Texas. He has taught undergraduate and MBA classes since 1995. Dr. Strong received his Ph.D. in Applied Management and Decision Sciences from Walden University in 1998, an MBA in Marketing from Amberton University in 1986, and a BBA in Management from the University of Texas at Austin in 1977. He has authored and co-authored several refereed journal and proceedings articles. His primary research interests are population projections, immigration implications, outsourcing, international trade, green jobs, diversity in the workplace, and organizational behavior. E-mail: drdstrong@ @bcglobal.net

\section{REFERENCES}

1. Bristow, M. (2010). "Drugs Fade in Colombian Economy," Wall Street Journal, World News Section, April 3, 2010.

2. Central Intelligence Agency of the United States (2011). The World Factbook: South America - Colombia. Retrieved from https://www.cia.gov/library/publications/the-world-factbook/geos/co.html

3. Charter Cities (2011). "Charter Cities: The Basics [Unabridged]." Retrieved from http://chartercities.org/concept

4. Departamento Administrativo Nacional de Estadística (DANE). (2011). Cuentas consolidadas y resultados generales Base 2000. Retrieved from http://www.dane.gov.co/en/index.php?option=com_content\&view=article \&id=313\&Itemid=84 
5. Dereciwz, M. (2011). Welcome to the Age of Aerotropolis. Endeavors. University of North Carolina at Chapel Hill, Spring, 2011: 24-29.

6. Hong Kong in Honduras. (2011, December 10). The Economist. Retrieved from http://www.economist.com/node/21541392

7. Jones, C. \& Romer, P. (2009). The New Kaldor Facts: Ideas, Institutions, Population, and Human Capital. National Bureau of Economic Research Working Paper 15094, June, 2009. Retrieved from http://www,nber.org/papers/w15094

8. Kasarda, J. (2007). "Size Doesn't Matter." Retrieved from www.aerotropolis.com/files/2007_03_Size.pdf

9. Kasarda, J. (2011a). Speed-Agility-Connectivity: Aerotropolis. Retrieved from http://www.aerotropolis.com/

10. Kasarda, J. (2011b). Aerotropolises and Airport Cities Listed. Updated September 13, 2011. Retrieved from http://www.aerotropolis.com/files/2011_AerotropolisStatus.pdf

11. Kasarda, J. \& Lindsay, G. (2011). Aerotropolis: The Way We'll Live Next. New York: Farrar, Straus and Giroux, 2011.

12. Kasarda, J., Rondinelli, D., \& Ward, J. (1996). The Global Transpark Network: Creating an Infrastructure Support System for Agile Manufacturing. National Productivity Review 16 (1), Winter 1996: 33-41.

13. López-Rodríguez, J. \& Acevedo, M. (2009, September 30). Second Nature Geography and Regional Income Disparities in Colombia. Working paper, Universidad de los Andes-Facultad de Economía-Cede Carrera 1 No. 18 A - 12, Bloque C. Bogotá, DC, Colombia. Retrieved from http://economia.uniandes.edu.co/

14. Mabe, M. (2008, August 20). "Survey Says: People Are Happier.” Bloomberg BusinessWeek, Global Section, August 20, 2008. Retrieved from http://www.businessweek.com/globalbiz/content/aug2008/gb20080820_874593.htm

15. Olivera, M. (2009). Road Infrastructure: An obstacle for economic growth in Colombia. Organization for Economic Cooperation and Development, 2009. Retrieved from www.oecd.org/dataoecd/34/26/46234518.pdf

16. Rise of the Aerotropolis. (2010, September 1). Business Facilities: The Location Advisor. Retrieved from http://businessfacilities.com/articles/cover-story/the-rise-of-the-aerotropolis/

17. Romer, P. (1986). Increasing Returns and Long-run Growth. Journal of Political Economy. October 1986, 94, 1002-1037.

18. Sequera, V. (2011, March 10). "Is Colombian 'dry canal' plan for real?” The Washington Post, March 10, 2011. Retrieved from http://www.washingtonpost.com/wpdyn/content/article/2011/03/10/AR2011031002777.html

19. Trading Economics. (2011). Colombia: National Statistical Data. Retrieved from: http://www.tradingeconomics.com/colombia/indicators

20. U. S Congress, House of Representatives, Committee on Ways and Means. (2011). The U.S.-Colombia Trade Agreement: An Opportunity to Expand the U.S. Infrastructure Sector \& Create U.S. Jobs. Retrieved from http://waysandmeans.house.gov/UploadedFiles/BradyInsert.pdf

21. World Bank (2011). Data by Country: Countries and Economies. Retrieved from http://data.worldbank.org/country 